Jurnal BASTRA (Bahasa dan Sastra) : http://ojs.uho.ac.id/index.php/BASTRA

\title{
GAYA BAHASA PERBANDINGAN DAN PENEGASAN DALAM NOVEL KUTUKAN TANAH BUTON KARYA SAFARUDIN
}

\section{OLEH}

\author{
Dedeh Ayu Aden Prastika Songohano', Aris Badara ${ }^{2}$, dan Sumiman Udu ${ }^{3}$ \\ ${ }^{1}$ Alumni Jurusan Pend. Bahasa dan Sastra Indonesia, ${ }^{2,3}$ Dosen Jurusan \\ Pendidikan Bahasa dan Sastra Indonesia, Fakultas Keguruan dan Ilmu \\ Pendidikan Universitas Halu Oleo
}

\begin{abstract}
ABSTRAK
Penelitian ini bertujuan untuk menemukan gaya bahasa perbandingan dan penegasan dalam novel Kutukan Tanah Buton karya Safarudin. Metode yang digunakan dalam penelitian ini adalah metode deskriptif kualitatif. Penelitian ini termaksud jenis penelitian kepustakaan. Sumber penelitian ini adalah novel Kutukan Tanah Buton karya Safarudin, yang diterbitkan pada tahun 2018. Teknik ppengumpulan data yang digunakan yaitu teknik baca catat. Data dalam penelitian di analisis menggunakan pendekatan stilistika. Hasil penelitian gaya bahasa dalam novel Kutukan Tanah Buton karya Safarudin meliputi (1) gaya bahasa perbandingan yaitu, (a) gaya bahasa simile, (b) gaya bahasa hiperbola, (c) gaya bahasa metafora, (d) gaya bahasa alegori dan (e) Personifikasi (2) Gaya bahasa penegasan yaitu, (a) gaya bahasa repitisi, (b) gaya bahasa aliterasi, (c) gaya bahasa elepsis, (d) gaya bahasa retoris, (e) gaya bahasa eklamasio, dan (f) gaya bahasa sindenton. Peristiwa dalam novel ini terjadi di tiga tempat yakni Kendari, Bau-bau dan Makassar.
\end{abstract}

Kata kunci : novel, gaya bahasa, perbandingan, penegasan 


\section{PENDAHULUAN}

\subsection{Latar Belakang}

Karya sastra merupakan suatu hasil imajinasi dan buah kreatifitas pengarang yang dihasilkan dalam bentuk tulisan. Tulisan yang bernilai karya sastra dilahirkan dari sederet kalimat-kalimat yang disusun dan dimanipulasi dengan rapi oleh pengarang. Pengarag meluapkan imajinasi dan ide-ide yang dimilikinya dengan penuh kesungguhan sehingga menghasilkan sebuah karya sastra yang dapat dinikmati oleh pembaca. Karya sastra juga dapat membuat penikmatnya terhipnotis oleh cerita-cerita yang disuguhkan. Hal ini karena fenomenafenomena kehidupan yang terjadi pada masyarakat dijadikan sebagai inspirasi oleh sastrawan untuk diwujudkan dalam sebuah karya sastra.

Dengan demikian, karya sastra itu hadir sebagai hasil perenungan pengarang terhadap fenomena kehidupan manusia, karya sastra juga tidak terlepas dari latar belakang pengarangnya. Hal ini berkaitan dengan implikasi kepengarangan dalam karyanya. Sehingga karya sastra itu tidak dianggap sekedar cerita khayal semata, akan tetapi hasil dari perwujudan kreativitas pengarang dalam berimajinasi dan menyampaikan gagasanya.

Inilah yang membuat peneliti tertarik untuk mengambil gaya bahasa perbandingan dan gaya bahasa penegasan dalam novel Kutukan Tanah Buton karya Safarudin yang terbit pada tahun 2018 oleh penerbit Oceania Press.

\subsection{Rumusan Masalah}

Berdasarkan latar belakang, maka masalah dalam penelitian ini adalah bagaimana gaya bahasa perbandingan dan gaya bahasa penegasan dalam novel Kutukan Tanah Buton karya Safarudin?

\subsection{Tujuan Penelitian}

Tujuan dalam penelitian ini adalah untuk mendeskripsikan gaya bahasa perbandingan dan gaya bahasa penegasan dalam novel Kutukan Tanah Buton karya Safarudin.

\subsection{Manfaat Penelitian}

Setiap penelitian akan memiliki manfaat tersendiri dari hasil penelitiannya. Adapun hasil yang diharapkan dari penelitian ini yaitu dapat menambah wawasan atau pengetahuan mengenai gaya bahasa dalam novel. Hasil dari penelitian ini juga diharapkan dapat bermanfaat dalam pembelajaran bahasa Indonesia, khususnya materi pembelajaran gaya bahasa, serta dapat dijadikan bahan acuan dalam penelitian selanjutnya.

\subsection{Batasan Operasional}

Untuk menghindari penafsiran yang ganda terhadap judul yang diteliti, maka peneliti memberikan batasan operasional sebagai berikut:

1. Novel merupakan salah satu karya seni yang diciptakan manusia yang mengandung rangkaian cerita kehidupan sosial dengan menonjolkan watak dan sifat setiap tokohnya.

2. Gaya bahasa adalah cara menggunakan bahasa yang memungkinkan kita dapat menilai pribadi, watak, dan kemampuan seseorang yang mempergunakan bahasa tersebut.

3. Stilistika merupakan sebuah metode analisis karya sastra yang mengkaji style dalam sebuah teks sastra.

\section{KAJIAN PUSTAKA \\ 2.1 Pengertian Novel}

Novel merupakan bentuk karya sastra yang paling populer di dunia, yaitu berupa prosa yang mengungkapkan sebagian kehidupan pelaku yang dianggap penting dan menarik. Bentuk sastra ini paling banyak beredar. Hal ini karena daya komunikasinya yang isinya dapat memanusiakan para pembacanya.

\subsection{Pengertian Gaya Bahasa}

Gaya bahasa merupakan cara khas yang digunakan oleh seorang penulis

140 | Jurnal BASTRA (Bahasa dan Sastra), Vol. 4 No.1, Edisi Januari 2019/e-ISSN: 2503-3875/ http://ojs.uho.ac.id/index.php/BASTRA 
dalam menuangkan gagasan yang dimilikinya dalam bentuk karya sastra melalui media tulisan. Tulisan yang ditulis tersebut sedemikian rupa disusun dengan menggunakan kata-kata sehingga membuat semakin indah sebuah tulisan tersebut. Penulis juga dengan pandai memainkan kata-kata sehingga membuat semakin indah sebuah tulisan tersebut.

Menurut Muhardi dan Hasanuddin WS (dalam Laila, 2016: 148) mengatakan bahwa gaya bahasa menyangkut kemahiran pengarang mempergunakan bahasa sebagai medium fiksi. Sejalan dengan pengertian diatas Ratna (dalam Laila, 2016: 148) menyatakan bahwa gaya bahasa juga merupakan pilihan kata tertentu sesuai dengan maksud penulis atau pembicara dalam rangka memperoleh aspek keindahan.

Gaya bahasa atau style merujuk pada keahlian untuk menulis indah. Sehingga gaya bahasa atau style adalah kemampuan dan keahlian untuk menulis atau mempergunakan kata-kata secara indah (Keraf, 2004: 112). Style atau gaya bahasa menurut Abrams (dalam Nurgiyantoro, 2010: 276) adalah cara pengucapan bahasa atau bagaimana seseorang pengarang mengungkapkan sesuatu yang akan dikemukakan.

\subsection{Jenis-Jenis Gaya Bahasa}

Beberapa para ahli membagi gaya bahasa dalam beberapa jenis gaya bahasa. Sebagaimana Waridah (2009: 322) membagi gaya bahasa menjadi empat kelompok gaya bahasa yakni, pertama, gaya bahasa pertentangan yang terdiri dari gaya bahasa antithesis, gaya bahasa paradoks, gaya bahasa oksimoron, gaya bahasa anakronisme, dan gaya bahasa kontradiksi interminus. Kedua, gaya bahasa perbandingan terdiri dari gaya bahasa metafora, gaya bahasa sinestesia, gaya bahasa simile, gaya bahasa alegori, gaya bahasa alusio, gaya bahasa metonimia, gaya bahasa hiperbola, gaya bahasa litotes, gaya bahasa personifikasi, gaya bahasa sinokdoke, gaya bahasa eufemisme, gaya bahasa perifrase, dan gaya bahasa simbolik. Ketiga, gaya bahasa penegasan yang terdiri dari gaya bahasa repetisi, gaya bahasa apofasis atau preterisio, gaya bahasa aliterasi, gaya bahasa paralelisme, gaya bahasa tautologi, gaya bahasa inverse, gaya bahasa elepsis, gaya bahasa retoris, gaya bahasa klimaks, gaya bahasa antiklimaks, gaya bahasa antanaklasis, gaya bahasa pararima, gaya bahasa koreksio, gaya bahasa eklamasio, gaya bahasa alonin, gaya bahasa interupsi, dan gaya bahasa silepsis. Keempat, gaya bahasa sindiran yang terdiri dari gaya bahasa ironi, gaya bahasa sarkasme, gaya bahasa antifrasis, dan gaya bahasa innuendo.

\subsubsection{Gaya Bahasa Perbandingan}

Gaya bahasa perbandingan adalah gaya bahasa yang menggunakan kata-kata kiasan dalam bentuk perbandingan untuk meningkatkan kesan kepada pembaca atau pendengar.

\subsubsection{Metafora}

Metafora adalah gaya bahasa yang membandingkan sesuatu dengan yang lain secara langsung. Menurut Waridah (2009: 330) metafora adalah gaya bahasa yang membandingkan tentang dua benda secara singkat dan padat.

Contoh :

$>$ Buku adalah jendela ilmu.

> "Suara rakyat adalah suara Tuhan", demikian ucapan salah seorang politikus.

\subsubsection{Sinestesia}

Sinestesia adalaha gaya bahasa berupa ungkapan yang berhubungan dengan suatu indera untuk dikenakan pada indera lain. Menurut Waridah (2009: 330) sinestesia adalah gaya bahasa yang mempertukarkan dua indera yang berbeda. Dengan demikian dapat disimpulkan bahwa makna sinestesia merupakan pergeseran makna suatu contoh kata dasar yang berkaitan dengan pancaindera.

Contoh : 
> Suasana pesta semakin hangat saat salah seorang tamu menyanyikan lagu kemesraan. (Hangat "indera peraba bertukar dengan indera penglihatan").

\subsubsection{Simile}

Simile merupakan gaya bahasa yang membandingkan sesuatu hal dengan hal lainnya. Menurut Waridah (2009: 331) simile adalah gaya bahasa perbandingan yang ditandai dengan kata depan dan penghubung seperti, layaknya, ibarat, bagai, umpama. Sekilas gaya bahasa simile mirip dengan gaya bahasa perumpamaan.

Contoh :

$>$ Ibarat ayam kurang mengekas, kurang makan.

\subsubsection{Alegori}

Alegori adalah gaya bahasa yang menjelaskan maksud tanpa secara harfiah. Umunya, alegori merujuk pada penggunaan retorika, namun alegori juga diungkapkan melalui lukisan atau pahatan. Menurut Waridah (2009: 331) alegori adalah gaya bahasa untuk mengungkapkan suatu hal melalui kiasan atau gambaran.

Contoh :

$>$ Nasib manusia tidak ada bedahnya dengan roda pedati, suatu waktu ia akan jatuh, merasa sakit dan menderita, pada saat yang lain akan tertawa dan berbahagia.

$>$ Perilaku para koruptor seringkali membuat kita marah. Mereka tidak jauh berbeda dengan tikus-tikus yang berkeliaran di lubang padi. Ia makan padi itu sepuasnya, tidak perduli di luar sana banyak manusia jadi kelaparan karena padinya rusak atau bahkan habis.

\subsubsection{Alusio}

Gaya bahasa yang digunakan dalam alusio merujuk pada peristiwa, legend, perumpamaan, tokoh, atau kejadiankejadian penting peristiwa pada masa lampau yang dianggap diketahui baik penutur maupun lawan bicara.
Contoh :

> Peristiwa 12 Mei 1998 menjadi lembaran hitam dalam perjalanan sejarah Republik indonesia.

$>$ Semangat Bandung Lautan Api menggelora di hati kami.

2.4.6 Metonimia

Metonimia adalah sebuah majas yang menggunakan sepatah-dua patah kata yang merupakan merek, macam atau lainnya yang merupakan satu kesatuan dari sebuah kata. Menurut Waridah (2009: 332) metonimia adalah gaya bahasa yang menggunakan nama merek atau atribut tertentu untuk menyebut suatu benda.

Contoh :

\subsubsection{Hiperbola}

Hiperbola mengandung suatu pernyataan yang berlebihan atau membesar-besarkan suatu hal dalam artian melebih-lebihkan apa yang sebenarnya, dengan maksud untuk memperhebat, meningkatkan kesan dan dayah pengaruh, baik jumlah, ukuran, maupun sifat-sifatnya.

Contoh:

$>$ Air matanya mengalir menganak sungai.

\subsubsection{Litotes}

Litotes adalah gaya bahasa yang bertujuan untuk menurunkan derajat atau merendahkan diri terhadap lawan bicara. Gaya bahasa ini biasanya terdengar berlebihan dan bertentangan dengan kenyataan si pembicara yang sebenarnya. Litotes merupakan gaya bahasa yang maknanya mengecilkan fakta dengan tujuan untuk merendahkan diri, Waridah (2009: 333-334).

Contoh :

Bantuan yang sedikit ini mudahmudahan cukup untuk membeli susu anak-anak. (Pada kenyataan, bantuan yang diberikan cukup besar dan dapat dimanfaatkan oleh seluruh anggota keluarganya. 


\subsubsection{Personifikasi}

Personifikasi adalah gaya bahasa yang melekatkan sifat-sifat insane (manusiawi) pada suatu benda mati sehingga seolah-olah memiliki sifat seperti benda hidup.

Contoh :

$>$ Angin topan mengamuk dan merobohkan puluhan rumah penduduk desa Sulu.

$>$ Kami duduk di tepi pantai sambil melihat ombak yang saling berkerjaran.

\subsubsection{Sinekdoke}

Sinekdoke adalah gaya bahasa yang menggunakan kata sebagian untuk menyatakan benda atau sesuatu secara keseluruhan dan sebaliknya. Gaya bahasa ini biasanya dapat kita temui dalam obrolan sehari-hari.

Contoh :

Pars pro toto :

$>$ Ina membeli lima dukuh manis.

$>$ Pak Imran memelihara sepuluh ekor kambing.

Totem pro toto :

$>$ Dunia mewaspadai badai ekonomi.

2.4.11 Eufemisme

Eufemisme adalah ungkapan yang lebih halus sebagai pengganti ungkapan yang dirasakan kasar. Contoh :

$>$ Perusahaan itu terpaksa merumahkan ribuan karyawannya. (Merumahkan karyawan nilai rasanya lebih halus dari pada memPHK).

\subsubsection{Perifrase}

Perifrase adalah gaya bahasa berupa pengungkapan yang panjang sebagai pengganti pengungkapan yang lebih pendek, atau, dengan kata lain suatu frasa panjang menggantikan frasa yang lebih pendek.

Contoh :

$>$ Di negeri Beruang Putih itu banyak bermunculan akademik sirkus. (Negeri Beruang Putih= Rusia).

\subsubsection{Simbolik}

Simbolik adalah gaya bahasa yang melukiskan sesuatu dengan menggunakan simbol benda, binatang atau tumbuhan. Menurut Waridah (2009: 336) simbolik adalah gaya bahasa untuk melukiskan suatu maksud dengan menggunakan simbol atau lambang.

Contoh :

$>$ Banyak tikus berkeliaran di gedung rakyat. (Tikus simbol bagi koruptor).

\subsubsection{Gaya Bahasa Penegasan}

\subsubsection{Repitisi}

Menurut Waridah (2009: 322) repitisi adalah pengulangan kata, frase, atau bagian kalimat yang dianggap penting untuk memberikan penekanan.

Contoh :

$>$ Bangunlah Bangsaku, bangunlah Negeriku, bangunlah dari tidurmu yang panjang, sambut cahaya di depan sana!

\subsubsection{Apofasis atau Preterisio}

Apofasis merupakan salah satu gaya bahasa yang penyampaiannya tegas seakan-akan melakukan penyangkalan mengacu pada penegasan sebuah pernyataan.

Contoh :

Tutur kata dan sikapnya yang baik seakan membius siapa pun yang ada di hadapannya. Entah apa yang akan terjadi bila mereka tahu sikap aslinya.

\subsubsection{Aliterasi}

Aliterasi dapat dijelaskan sebagai pengulangan huruf mati pada beberapa suku-kata yang berturut-turut, biasanya suku-kata awal setiap kata. Aliterasi merupakan salah satu unsur pembentuk irama sajak awal.

Contoh :

Mengalir, menimbu, mendesak, mengepung, memenuhi, sukma, menawan tubuh.

("Perasaan seni," J,E. Tatengkeng).

2.5.4 Pleonasme 
Menurut Waridah (2009: 323) pleonasme adalah suatu pikiran atau gagasan yang disampaikan secara berlebihan, sehingga ada beberapa keterangan yang kurang dibutuhkan.

\section{Contoh :}

$>$ Nama-nama yang sudah kami sebutkan sebelumnya, mohon maju ke depan.

\subsubsection{Paralelisme}

Gaya bahasa paralelisme merupakan gaya bahasa yang memberikan dua atau lebih bagian dari seluruh kalimat bentuk yang sama sehingga memberikan pola tertentu.

Contoh :

$>$ Baik golongan yang tinggi maupun golongan yang rendah harus diadili kalau bersalah.

\subsubsection{Tautologi}

Secara etimologis, tautology berasal dari bahasa latin "tautologia", yang memiliki arti pengulangan makna. Menurut KBBI diartikan sebagai pengulangan pernyataan, gagasan, atau kata yang berlebih dan sebenarnya tidak diperlukan karena memiliki makna yang sama. Menurut Waridah (2009: 323) tautologi adalah gaya bahasa berupa perulangan kata dengan menggunakan sinonimnya.

Contoh :

$>$ Apa maksud dan tujuanmu datang ke sini sepagi ini ?

\subsubsection{Inversi}

Inversi merupakan gaya bahasa yang susunan predikatnya mendahului subjek (P-S-K). inversijuga merupakan kebalikan dari versi yang dimana versi unsur pola kalimatnya tersusun berurutan (S-P-O-K).

Contoh :

$>$ Ada perbedaan sudut pandang antara saya dan dia.

Bersih sekali kamarmu.

\subsubsection{Elipsis}

Elepsis merupakan gaya bahasa yang menghilangkan sebagian kata-kata atau kalimatnya. Sebagaimana menurut Waridah (2009: 324) elipsis adalah gaya bahasa yang menghilangkan beberapa unsur kalimat, unsur-unsur yang hilang tersebut muda ditafsirkan oleh pembaca.

Contoh :

Andai saja kamu mau mengikuti saranku, tentu... sudalah semuanya sudah terjadi, tidak perlu dibicarakan lagi.

\subsubsection{Retoris}

Retoris adalah majas yang berupa pertanyaan yang sebenarnya tidak perlu dijawab, karena jawaban atau maksud dari penanya sudah terkandung dalam pertaanyaan tersebut. Retoris juga diartikan sebgai gaya bahasa untuk menanyakan sesuatu yang jawabannya telah terkandung dalam pernyataan tersebut Waridah (2009: 324).

Contoh :

$>$ Manusia mana yang tidak butuh uang ?

berangsur-angsur.

Contoh :

$>$ Seluruh warga mulai dari anakanak, remaja, hingga orang tua turut hadir dalam acara pembukaan panti asuhan itu.

\subsubsection{Antiklimaks}

Dalam KBBI antiklimaks diartikan sebagai kemerosotan atau kemunduran mendadak sampai taraf yang tidak berarti dan amat mengecewakan, sangat berlawanan dengan kemajuan atau kehebatan yang telah dicapai sebelumnya. Antiklimaks juga merupakan suatu hal yang berturutturut yang makin lama makin menurun. Menurut Waridah (2009: 325) antiklimas adalah gaya bahasa yang bergantung dalam kata-kata yang diucapkannya, yaitu semakin lama semakin menurun.

\section{Contoh :}

$>$ Kepala sekolah, guru, dan siswa memiliki tanggung jawab yang sama dalam menjaga keamanan dan kebersihan sekolah. 
2.5.12 Antanaklasis

Antaklasis merupakan gaya bahasa yang menunjukan pengulangan kata yang sama tetapi memiliki makna yang berbeda. Menurut Waridah (2009: 325) antanaklasis adalah gaya bahasa yang menggunakan pengulangan kata yang sama tetapi maknanya berlainan.

Contoh :

$>$ Seringkali ibu mengingatkan Nino untuk tidak bermainan di kali.

> Pak Saiman menonton ketoprak kesukaannya.

\subsubsection{Pararima}

Menurut Waridah (2009: 325) pararima adalah bentuk pengulangan konsonan awal dan akhir dalam kata atau bagian yang berlainan.

Contoh :

$>$ Pengemis dan anak-anak jalan kocar-kacir saat petugas Satpol PP melakukan penerbitan.

\subsubsection{Koreksio}

Koreksio adalah sebuah gaya bahasa yang digunakan untuk mempertegas sesuatu pernyataan dengan cara membuat pernyataan pertama yang kemudian pernyataan tersebut dikoreksi dengan diperbaiki atau diganti dengan pernyataan lain. Contoh :

$>$ Kalau tidak salah, saya pernah menyampaikan hail ini dua hari yang lalu. Ah, bukan kemarin.

\subsubsection{Sindenton}

Sindenton merupakan gaya bahasa yang pengungkapan kalimatnya atau wacana yang bagian-bagiannya dihubungkan dengan kata penghubung. Sindenton juga memiliki artian yaitu gaya bahasa untuk mengungkapkan sesuatu kalimat atau wacana yang setiap bagiannya dihubungkan oleh kata penghubung Waridah (2009: 325).

Contoh :
$>$ Setelah merapikan tempat tidur, lalu dia mandi, kemudian bersiapsiap untuk berangkat ke sekolah dan tidak lupa ia berpsmitan kepada orang tuanya.

\subsubsection{Eklamasio}

Eklamasio merupakan gaya bahasa yang mengandung ungkapan dengan menggunakan kata-kata seru. Sedangkan menurut Waridah (2009: 326) eklamasio adalah gaya bahasa yang menggunakan kata seru.

Contoh :

> “Ah... lupakan saja!"

$>$ Wow, sungguh luar biasa! Ternyata kamu mampu membuat lukisan sekelas Afandi.

\subsubsection{Alonim}

Alonim merupakan gaya bahasa yang menggunakan variasi lain dari nama sesuatu sebagai bentuk penegasan. Menurut Waridah (2009: 326) alonim adalah penggunaan varian dari nama untuk menegaskan.

Contoh :

$>$ "Iya... iya...Mbak ngerti. Tapi ada embak di sini jangan takut, Ning"

"Tapi mereka akan terus menuduh Wening orawaras, Mbak. Padahal Wening sudah sembuh.

\subsubsection{Interupsi}

Interupsi dapat diartikan selaan atau pemotongan. Jadi gaya bahasa interupsi dapat diartikan sebuah gaya bahasa dimana terdapata selaan atau sisipan sebuah frasa pada unsur kalimat. Menurut Waridah (2009: 327) interupsi adalah gaya bahasa yang menyisipkan keterangan tambahan diantara unsur-unsur kalimat.

Contoh :

$>\mathrm{Bu}$ Sainah, seorang pedagang pecel keliling, mendapat hadiah sepeda motor dari sebuah sayembara.

$>$ Pak Amri, guru teladan SMP Fajar Taruna, mendapat penghargaan dari Gubernur Jawa Barat.

2.5.19 Preterito 
Preterito merupakan gaya bahasa yang digunakan untuk menyembunyikan atau merahasiakan sesuatu sehingga pembaca atau lawan bicara menerka apa yang disembunyikan. Selain itu, preteritorio adalah ungkapan penegasan dengan cara menyembunyikan maksud yang sebenarnya Waridah (2009: 327).

Contoh :

$>$ Tolong jangan beritahu dia, bahwa aku sudah tidak mencintainya lagi.

\subsubsection{Silepsis}

Silepsis merupakan gaya bahasa yang menegaskan sesuatu hal dengan menggunakan satu kata yang memiliki satu tau lebih makna yang berfungsi pada satu atau lebih kontruksi sintaksis.

Contoh :

$>$ Saya memahami keadaan dirinya sebagai keadaan diriku. Seharusnya: saya memahami keadaan dirinya sebagaimana ia memahami keadaan diriku.

$>$ Apa bisnis utamamu ? menjual mobil atau menyewakan?. Seharusnya: apa bisnis utamamu ? menjual atau menyewakan mobil ?

\subsection{Pendekatan Stilistika}

Di dalam mengetahui sebuah style karya sastra maka harus dilakukan melalui sebuah pendekatan. Salah satu pendekatan yang mengkaji teks karya sastra adalah pendekatan stilistika. Pendekatan stilistika bertolak belakang dari asumsi bahwa bahasa mempunyai tugas dan peranan yang penting dalam kehadiran karya sastra.

\section{METODE PENELITIAN}

\subsection{Metode dan Jenis Penelitian}

\subsubsection{Metode Penelitian}

Pada metode ini metode yang digunakan adalah metode deskriptif kualitatif. Metode kualitatif yang dimaksudkan sebagai jenis metode penelitian yang temuannya tidak diperoleh melalui prosedur statistik atau bentuk hitungan lainnya tetapi metode ini menjelaskan data dan menyajikan secara langsung data yang diteliti. Metode deksriptif maksudnya penyajian data secara terurai berdasarkan kenyataankenyataan objektif sesuai dengan yang terdapat dalam novel Kutukan Tanah Buton karya Safarudin. Metode kualitatif digunakan untuk menguraikan konsepkonsep pemahaman dan pemberian interpertasi yang disampaikan secara verbal dan pedoman pada teori-teori sastra yang relevan dengan novel sebagai objek kajian dalam penelitian ini.

\subsubsection{Jenis Penelitian}

Jenis penelitian yang digunakan dalam penelitian ini adalah penelitian kepustakaan (library research) dikatakan kajian kepustakaan karena kajian dalam penelitian ini berupa data tertulis dan kegiatan dalam mencari, mengumpulkan, dan mendapatkan data-data yang diperlukan dengan cara menelaah dan menganalisis penggunaan gaya bahasa dengan objek kajian berupa buku novel Kutukan Tanah Buton karya Safarudin. Selain itu, peneliti mengadakan studi lewat sejumlah bacaan yang relevan dan mendukung penelitian ini.

\subsection{Data dan Sumber Data}

\subsubsection{Data}

Data yang digunakan dalam penelitian ini adalah data tertulis berupa teks novel, yang memuat sejumlah gaya Bahasa dalam novel Kutukan Tanah Buton karya Safarudin.

\subsubsection{Sumber Data}

Sumber data dalam penelitian ini berupa sumber data tertulis dalam novel Kutukan Tanah Buton karya Safarudin yang diterbitkan oleh Oceania Press, kendari, Cetakan pertama 2018, terdiri atas 366 halaman. 


\subsection{Teknik Pengumpulan Data}

Teknik pengumpulan data dalam penelitian ini adalah:

1. Teknik baca, yaitu membaca secara analisis novel Kutukan Tanah Buton karya Safarudin.

2. Teknik catat, yakni mencatat data-data atau informasi yang diperoleh dari hasil pembacaan mengenai gaya bahasa yang terdapat dalam novel Kutukan Tanah Buton karya Safarudin.

\subsection{Teknis Analisis Data}

Dalam penelitian ini yang menjadi objek utama yang akan dianalisis adalah gaya bahasa perbandingan dan gaya bahasa penegasan dalam naskah novel Kutukan Tanah Buton karya Safarudin.

Adapun langkah-langkah dalam menganalisis data sebagai berikut:

1. Setelah membaca novel, peneliti mengidentifikasi data mengenai gaya bahasa dan diberi tanda.

2. Klasifikasi data, yaitu mengklasifikasikan atau mengelompokan data berdasarkan permasalahan dalam penelitian ini adalah data mengenai gaya bahasa dalam novel Kutukan Tanah Buton karya Safarudin.

3. Deskripsi data, yaitu menjelaskan data mengenai gaya bahasa telah diklasifikasikan atau dikelompokan dalam bentuk kebahasaan.

4. Analisis data, yaitu untuk menemukan gaya bahasa dalam novel Kutukan Tanah Buton karya Safarudin.

\section{HASIL PENELITIAN}

\section{DAN PEMBAHASAN}

\subsection{Gaya Bahasa Perbandingan dan Penegasan dalam Novel Kutukan Tanah Buton karya Safarudin}

Penulis telah melakukan analisis dalam novel Kutukan Tanah Buton karya Safarudin. Analisis yang dilakukan dengan tahap pembacaan menyeluruh, mengelompokan gaya bahasa dalam novel tersebut. Dalam analisis ini di gunakan dua gaya bahasa yaitu gaya bahasa perbandingan dan penegasan. Gaya bahasa perbandingan yang terdapat dalam novel Kutukan Tanah Buton karya Safarudin yaitu :

\subsubsection{Gaya Bahasa Perbandingan}

Gaya bahasa perbandingan adalah gaya bahasa yang menggunakan kata-kata kias untuk membandingkan dan meningkatkan kesan dari suatu kalimat terhadap pembaca atau pendengar. Gaya bahasa perbandingan terbagi menjadi 13 gaya bahasa yang terdiri dari metafora, sinestesia,simile, alegori, alusio,metonomia, hiperbola, litotes, personifikasi, sinekdoke, eufemisme, perifrase dan simbolik.

Penggunaan gaya bahasa ini di dalam novel Kutukan Tanah Buton karya Safarudin, diuraikan sebagai berikut :

\subsubsection{Gaya Bahasa Simile}

Gaya bahasa simile adalah gaya bahasa yang ditandai dengan kata depan dan penghubung seperti layaknya, ibarat, bagaikan, seperti, bagai, umpama.. Penggunaan gaya bahasa simile di dalam novel Kutukan Tanah Buton karya Safarudin, terdapat pada bagian ke-4, paragraf ke-1, halaman ke- 2, diuraikan sebagai berikut :

Gaya bahasa simile juga terdapat pada bagian ke-8, paragraf ke-1, halaman ke-9, diuraikan sebagai berikut :

"Ah.. rupanya kuliah itu tidak mudah seperti yang aku pikirkan," bisikku dalam hati ( Safarudin, 2018: 9)".

Pada kutipan di tersebut, gaya bahasa simile terdapat pada kata penghubung "seperti". Kata "seperti" membuka pikiran seseorang bahwa kuliah itu tidak semudah yang dia pikirkan. Makna dari ungkapan di atas yakni menuntut ilmu itu tidak semudah yang kita bayangkan. Salah satunya kuliah karena kuliah merupakan perolehan ilmu dan gelar ke jenjang yang lebih tinggi lagi. 
Gaya bahasa simile juga terdapat pada bagian ke-6, paragraf ke-6, halaman ke-55, diuraikan sebagai berikut :

"Aku tak bisa menggambarkan keindahannya karena begitu indah dan kuatnya keinginanku untuk memasuki seperti kuatnya tiang bendera Buton yang berdiri di depan masjid Keraton Buton" kataku padanya ( Safarudin, 2018: 55)".

Pada kalimat di atas, gaya bahasa simile terdapat pada kata penghubung seperti. Kata penghubung seperti pada kalimat di atas memiliki makna seseorang yang begitu mengagumi sesuatu dan bertekad untuk memilikinya. Seorang yang memiliki tekad yang kuat dan tegak, hal tersebut dapat dilihat dari kata seperti kuatnya tiang bendera yang berdiri di depan masjid Keraton Buton.

\subsubsection{Gaya Bahasa Hiperbola}

Gaya bahasa hiperbola adalah gaya bahasa yang bersifat melebih-lebihkan suatu kenyataan. Fungsi dari gaya bahasa hiperbola yaitu untuk menguatkan kesan makna yang sesungguhnya. Dalam novel Kutukan Tanah Buton karya Safarudin gaya bahasa hiperbola terdapat pada bagian ke-8, paragraf ke-3, halaman ke-3, diuraikan sebagai berikut :

"Kalau saja aku tidak mengingat itu semua, mungkin di hari pernikahanmu itu sebelum ijab Kabul aku telah mati, mati bunuh diri karena cinta ( Safarudin, 2018: 3)".

Pada kutipan di atas, gaya bahasa hiperbola terdapat pada kata "mati bunuh diri karena cinta". Penggunaan kata "mati bunuh diri karena cinta" pada kutipan di atas sangat di lebihlebihkan, karena tidak semestinya persoalan putus cinta lalu ia rela mati bunuh diri. Sedangkan ibu dan saudara-saudaranya sangat menyayanginya. Makna dari ungkapan di atas ialah seseorang yang masih berpikir panjang untuk tidak bunuh diri, mengingat keluarganya sangat menyayangi dirinya.

Gaya bahasa hiperbola juga terdapat pada bagian ke-1, paragraf ke-2, halaman ke-48, diuraikan sebagai berikut :

"Pagi yang dingin dan sinar matahari ternyata telah membawa cinta dalam hatiku. Suhu dingin di pagi itu telah membekukan hatiku untuk yang lain dan sinar matahari di pagi itu pula telah membangun cinta dalam hati ( Safarudin, 2018: 48)".

Pada kutipan di atas gaya bahasa hiperbola terdapat pada kata "membekukan". Penggunaan kata "membekukan" dalam kutipan di atas solah-olah melebihkan suasana, sehingga terkesan membuat seseorang tidak nyaman. Makna ungkapan pada kutipan di atas ialah suasana di pagi hari yang sangat dingin sampai membekukan hatinya.

Gaya bahasa hiperbola juga terdapat pada bagian ke-1, paragraf ke-1, halaman ke-76, diuraikan sebagai berikut :

"Panas di siang itu telah terkalahkan oleh dinginnya suhu tubuh antara aku dan Aulia ( Safarudin, 2018: 76)".

Pada kutipan di atas, gaya bahasa hiperbola terdapat pada kata "terkalahkan". Kata "terkalahkan" pada kutipan di atas melebih-lebihkan suasana di siang hari itu yang menjadi sangat dingin. Makna dari ungkapan di atas ialah mereka tak merasakan panasnya di siang itu karena dinginnya suhu tubuh mereka berdua.

\subsubsection{Gaya Bahasa Metafora}

Metafora adalah gaya bahasa yang membandingkan sesuatu dengan yang lain secara langsung. Penggunaan gaya bahasa metafora di dalam novel Kutukan Tanah Buton karya Safarudin, terdapat pada bagian ke-2, paragraph ke-1, halaman ke 71, diuraikan sebagai berikut : 
"Janganlah terpesona akan keindahan karena belum tentu keindahan itu tak memiliki duri ( Safarudin, 2018: 71)". Pada kutipan di atas, makna gaya bahasa metafora memiliki makna kita sebagai manusia jangan mudah terpesona oleh keindahan, karena belum tentu keindahan itu tidak memiliki duri yang dapat melukai.

\subsubsection{Gaya Bahasa Alegori}

Alegori merupakan gaya bahasa yang menjelaskan maksud tanpa secara harfiah, yang pada umumnya merujuk pada ungkapan suatu hal melalui kiasan, gaya bahasa alegori terdapat pada bagian ke-1, paragraf ke-3, halaman ke-164, diuraikan sebagai berikut :

"Dalam merubah hidup manusia tak perlu meratapi masa lalu dan khayalan-khayalan yang dibuatnya. Hidup harus berani, berani keluar dari kekerdilan berpikir dan berani menimbulkan jiwa keberanian dari dasar ketaksadaran yang abstrak ( Safarudin, 2018: 164)".

Makna dari gaya bahasa di atas ialah manusia tidak boleh selamanya meratapi masa lalu, kita harus berani keluar dari masa lalu yang dapat menghambat masa depan kita.

Gaya bahasa alegori terdapat pada bagian ke-1, paragraph ke-3, halaman ke- 325, diuraikan sebagai berikut :

"Memang buah itu jatuh tidak jauh dari pohonnya, tapi aku tak mau menjadi buah itu. seorang ayah yang menikah lagi dengan wanita lain bagiku cintanya tak seteguh pohon yang menghasilkan buah itu, cintanya mudah dibagi dan bahkan dicaci, aku tak bisa seperti itu ( Safarudin, 2018: 326)".

Kutipan dari gaya bahasa di atas memiliki makna yaitu, dia tak ingin seperti ayahnya yang tidak setia kepada istrinya.

\subsubsection{Gaya Bahasa Personifikasi}

Personifikasi adalah gaya bahasa yang meletakan sifat-sifat insane (manusiawi) pada suatu benda mati sehingga seolah-olah memiliki sifat seperti benda hidup. Gaya bahasa personifikasi terdapat pada bagian ke1, paragraf ke-1, halaman ke-76, diuraikan sebagai berikut :

"Udara dan angin pantai selalu bertamu dipernapasan kami setiap saat, karena letak kampungku berada dipesisir pantai Laut Banda ( Safarudin, 2018: 76)".

Pada kutipan di atas makna gaya bahasanya yaitu kerasnya ombak yang di sertai angin keras. Hal tersebut terjadi karena kampung halamannyaberada di pesisir pantai.

\subsubsection{Gaya Bahasa Penegasan}

Gaya bahasa penegasan adalah gaya bahasa yang bertujuan untuk menegaskan sesuatu sehingga tibul kesan mendalam bagi pembaca maupun pendengar. Gaya bahasa penegasan terbagi menjadi 20 gaya bahasa yang terdiri dari, Repitisi, apofasis, aliterasi dan pleonasme,paralelisme, tautologi, inverse, elipsis, retoris, klimaks, antiklimaks, antanaklasis, pararima, koreksio,sindenton, eklamasio, alonim, interupsi, preterito dan silepsis.

Penggunaan gaya bahasa penegasan dalam novel Kutukan Tanah Buton karya Safarudin, diuraikan sebagai berikut.

\subsubsection{Gaya Bahasa Repitisi}

Gaya bahasa repitisi adalah gaya bahasa perulangan kata frase, atau bagian kalimat yang dianggap penting untuk memberikan penekanan. Fungsi gaya bahasa repitisi yaitu membentuk kata atau frasa atau klausa. Penggunaan gaya bahasa repitisi dalam novel Kutukan Tanah Buton karya Safarudin, diuraikan sebagai berikut : 
"Menikah. Itulah pintu surga di mataku, tempulah jalan itu dan dapatkanlah surga itu katamu di Benteng Keraton Buton di suatu senja. Dirimu begitu meyakinkanku untuk menemui kedua orang tuamu, katamu harta belum tentu menjadi jalan menuju kebahagiaan ( Safarudin, 2018: 1)”.

Pada kalimat di atas repetisi terdapat pada kata surga yang diulang beberapa kali pada awal kalimat. Penggunaan kata surga dalam kalimat atas bermakna bahwa suatu kebahagian yang ingin di capai oleh seorang wanita bersama pria yang dicintainya. Sehingga wanita itu meyakinkan pria tersebut untuk menemui kedua orang tuanya, dan baginya harta bukanlah syarat menuju suatu kebahagiaan.

Gaya bahasa repitisi juga terdapat pada bagian ke-1, pararaf ke-1, halaman ke-47 diuraikan sebagai berikut :

"Maafkan diriku yang memikirkanmu diam-diam, aku tahu ini dosa, tapi aku tak sanggup menghilangkannya. Aku tak ingin menjadi majnum yang mati karena cintanya tak didapatkannya, aku harus berani mengatakan kebenarannya tentang yang kurasakan padamu ( Safarudin, 2018: 47)".

Pada kalimat di atas gaya bahasa repitisi terdapat pada kata $a k u$ yang di ulang beberapa kali di setiap awal kalimat. Penggunaan kata $a k u$ dalam kalimat di atas bermakna bahwa seorang yang jatuh cinta dan memikirkan wanita tersebut secara diam-diam walaupun dia tau bahwa yang di lakukan ini adalah dosa. Sehingga dia mencoba untuk memberanikan diri dalam mengungkapkan perasaannya tersebut.

\subsubsection{Gaya Bahasa Aliterasi}

Gaya bahasa aliterasi adalah pengulangan konsonan pada awal kata secara berurutan. Fungsi gaya bahasa aliterasi yaitu sebagai pengulangan bunyi huruf pada awal kalimat, suatu kalimat yang terdapat dua kali atau lebih pengulangan bunyi di awalan kata yang sama. Penggunaan gaya bahasa aliterasi dalam novel Kutukan Tanah Buton karya Safarudin, diuraikan sebagai berikut :

"Apa salahku bu, apakah salah aku mencintai Aulia ?" ( Safarudin, 2018: 315)".

Pada kalimat di atas aliterasi terdapat pada perulangan konsonan "s" pada awal kata salahku secara berurutan. Makna dari ungkapan di atas ialah "seorang yang mencintai wanita, akan tetapi seakan-akan cintanya tidak mendapatkan restu dari ibunya. Sehingga dia bertanya pada ibunya, apa salahnya jika mencintai wanita tersebut".

\subsubsection{Gaya Bahasa Elepsis}

Gaya bahasa elepsis adalah gaya bahasa yang menghilangkan beberapa unsur kalimat. Fungsi gaya bahasa elepsis yaitu menghilangkan salah satu unsure dalam wacana atau kalimat. Unsur-unsur tersebut sangat mudah ditafsirkan oleh pembaca. Penggunaan gaya bahasa elepsis dalan novel Kutukan Tanah Buton karya Safarudin, diuraikan sebagai berikut :

"Ya... mungkin ini belum rejeki saya pak, mungkin tahun depan baru bisa saya ikut pak" Aku menjawab dengan tertunduk lesuh (Safarudin, 2018: 12)".

Pada kalimat di atas elepsis terdapat pada penghilangan kata yang ditandai dengan pemberian tanda titik tiga. Kata yang dihilangkan sangat mudah ditafsirkan oleh pembaca karena masing-masing pembaca memiliki cara tafsir yang berbeda-beda.

\subsubsection{Gaya Bahasa Retoris}

Gaya bahasa retoris adalah gaya bahasa untuk menanyakan sesuatu yang jawabannya telah terkandung 
dalam pertanyaan tersebut. Penggunaan gaya bahasa retoris dalam novel Kutukan Tanah Buton karya Safarudin, diuraikan sebagai berikut :

"Dengan uang yang secukupnya apakah aku bisa bertahan mengikuti ujian tes selama tiga hari di kota yang serba membutuhkan uang ? hanya tekad optimislah yang kutanamkan dalam hatiku saat itu (Safarudin, 2018: 16)". Pada kalimat di atas retoris juga terdapat pada penempatan kata tanya yang terletak pada ungkapan "apakah aku bisa bertahan mengikuti ujian tes selama tiga hari di kota yang serba membutuhkan uang?". Makna dari ungkapan kata tanya tersebut ialah seseorang yang mempertanyakan sesuatu pada dirinya dan jawabannya telah terkandung dalam pertanyaan tersebut.

Gaya bahasa retoris juga terdapat pada bagian ke-1, paragraf ke-5, halaman ke-49, yang diuraikan sebagai berikut:

"Apakah dirimu bersedia menerima perasaan yang ala kadarnya ini ? jawablah seperti yang dikatakan kata hatimu karena diantara kita menginginkan cinta kejujuran ( Safarudin, 2018: 49)".

Pada kalimat di atas, gaya bahasa retoris terdapat pada penempatan tanda tanya yang terletak pada ungkapan "Apakah dirimu bersedia menerima perasaan yang ala kadarnya ini ?". Makna dari ungkapan kata tanya tersebut ialah seseorang yang mempertanyakan sesuatu hal yang jawaban dari pertanyaan tersebut telah terkandung dalam kalimat pertanyaan itu.

\subsubsection{Gaya Bahasa Eklamasio}

Gaya bahasa eklamasio adalah gaya bahasa yang menggunakan kata seru.fungsi eklamasio yaitu untuk menegaskan suatu kalimat. Penggunaan gaya bahasa eklamasio dalam novel Kutukan Tanah Buton karya Safarudin, yang diuraikan sebagai berikut :

"Semenjak kecil, aku sangat ingin menjadi seorang tentara, entah mengapa itulah cita-citaku dan tak sedikitpun terpikirkan olehku untuk kuliah, bahkan aku sering mendengar teman-teman bercerita tentang perkuliahan tapi anehnya aku sama sekali tidak tertarik dan tidak merespon, karena pada saat itu yang ada dibenakku hanya ingin menjadi seorang tentara TITIK...!! (Safarudin, 2018: 6)".

Gaya bahasa eklamasio juga terdapat pada bagian ke-6, paragraf ke-3, halaman ke-60, diuraikan sebagai berikut :

"Iya, masa depan. "Aku ingin ke masa depan bersamamu!'jawabku. Hehehe.. Aulia tertawa ( Safarudin, 2018: 60)". Pada kalimat di atas, gaya bahasa eklamasio terdapat pada penempatan tanda seru pada ungkapan "Aku ingin ke masa depan bersamamu!". Makna dari ungkapan di atas ialah ungkapan perasaan seseorang untuk ke masa depan bersam orang yang di cintainya. Gaya bahasa eklamasio juga terdapat pada bagian ke-3, paragraf ke-3, halaman ke-73, diuraikan sebagai berikut :

"Aku takut?" kata Aulia. "Takut apa ?" tanyaku padanya. "Takut kehilangan !" ( Safarudin, 2018: 73)".

Pada kalimat di atas, gaya bahasa eklamasio juga terdapat pada penempatan tanda seru pada ungkapan "Takut kehilangan !". Makna dari ungkapan di atas ialah ungkapan perasaan seseorang yang takut akan kehilangan wanita yang di cintainya.

Gaya bahasa eklamasio juga terdapat pada bagian ke-3, paragraf ke-1, halaman ke-89, diuraikan sebagai berikut :

"Aku akan menikah dengan gadis kota di Makassar !" tanpa terbata-bata aku menjawabnya membuat saudarasaudara kandungku tertawa terbahak- 
bahak sambil mengelitikku sehingga membuat diriku ikut tertawa juga ( Safarudin, 2018: 89)".

Gaya bahasa eklamasio juga terdapat pada bagian ke-1, paragraf ke-2, halaman ke-95, diuraikan sebagai berikut :

"Ayahmu keturunan ode di Buton ini nak !" kata ibu. Tapi mengapa disetiap nama kalian tidak ada ode-odenya karena ompu-omputo wahandeini ndesianemo ode ndehae ( Safarudin, 2018: 95)".

Pada kalimat di atas gaya bahasa eklamasio terdapat tanda seru pada ungkapan "Ayahmu keturunan ode di Buton ini nak !’. Makna dari ungkapan di atas ialah seorang ibu yang memberi penegasan pada anaknya bahwa ayahnya merupakan keturunan ode di Buton.

\subsubsection{Gaya Bahasa Sindenton}

Sindenton merupakan gaya bahasa yang mengungkapkan kalimatnya atau wacana yang bagian-bagiannya dihubungkan dengan kata penghubung. Gaya bahasa sindenton terdapat pada bagian ke-9, paragraf ke-1, halaman ke-1, diuraikan sebagai berikut :

"Kala itu dirimu begitu yakin menyemangati seorang anak yatim piatu yang akan datang menemui kedua orang tuamu yang berada dan beradat di Makassar ( Safarudin, 2018: 2)".

Kutipan di atas memiliki makna yaitu seorang yang betuh debgan semangat untuk menemui kedua orang tua kekasihnya, yang beradat dan berada.

Gaya bahasa sindenton terdapat pada bagian ke-2, paragraph ke-3, halaman ke-16, diuraikan sebagai berikut :

"Dibalik kaca riben mobil itu kulihat lambaingan tangan ibuku, lambaian pengiring kepergianku, dari kaca mobil itu kupandangi ibu yang telah melahirkanku di dunia ini ( Safarudin, 2018: 16)".

Pada kutipan bahasa sindenton di atas, memiliki makna seorang anak yang selalu meyayangi dan mencintai ibunya yang telah melahirkannya di dunia ini.

Gaya bahasa sindenton juga terdapat pada bagian ke-3, paragraf ke-3, halaman ke-18, diuraikan sebagai berikut :

"Bapak wali kelasku yang memberitahunya bahwa aku akan menginap di rumahnya selama tiga hari, mendengar itu, ibu Yusna langsung menelfonku dia memarahiku, katanya jangan malumalu dating ke rumahnya ( Safarudin, 2018: 18)".

Dari kutipan di atas memiliki makna bahwa seorang guru yang perduli terhadap siswanya dan melarangnya untuk malu-malu.

\subsection{Relevansi Pembelajaran di Sekolah}

Sekolah merupakan tempat dimana anak didik dibekali ilmu pengetahuan untuk arah tujuan hidupnya. Melalui proses pembelajaran peserta didik dapat mengembangkan potensi dirinya untuk membentuk kepribadian yang baik, kecerdasan, akhlak yang mulai, dapat berguna bagi masyarakat, serta bagi bangsa dan negara. Melalui karya sastra pula dapat membentuk karakter anak didik menjadi baik.

Karena melalui sastra itulah mereka dapat mengambil manfaat yang baik untuk dirinya. Sebagaimana tujuan dari pembelajaran sastra di sekolah yakni agar siswa dapat menggunakan bahasa Indonesia untuk meningkatkan kemampuan intelektual dan kemampuan berbahasa, menikmati dan memanfaatkan karya sastra untuk memperluas wawasan, memperluas budi pekerti, kematangan emosional dan sosial, menghargai dan mengembangkan karya sastra Indonesia. 


\section{PENUTUP}

\subsection{Kesimpulan}

Berdasarkan hasil penelitin dan pembahasan pada penelitian analisis gaya bahasa perbandingan dan penegasan pada novel Kutukan Tanah Buton karya Safarudin, dapat diperoleh kesimpulan di bawah ini.

Berdasarkan hasil penelitian, menunjukan bahwa dalam novel Kutukan Tanah Buton karya Safarudin terdapat 2 gaya bahasa perbandingan dan terdapat 5 gaya bahasa pertentangan. Kedua gaya bahasa perbandingan itu ialah gaya bahasa simile dan hiperbola, sedangkan pada gaya bahasa penegasan yaitu gaya bahasa repitisi, aliterasi, elepsis, retoris dan eklamasio.

Penggunaan gaya bahasa

perbandingan dan pertentangan yang bervariasi menambah keindahan pada novel Kutukan Tanah Buton karya Safarudin. Selain itu, pemakaian berbagai macam gaya bahasa perbandingan dan penegasan mempunyai peranan penting dalam mendukung karangan seorang penulis Safarudin.

\subsection{Saran}

Berdasarkan hasil analisis sampai dengan rumusan kesimpulan di atas, maka penulis menyampaikan beberapa hal.

Perlu adanya peningkatan dalam penelitian sastra pada umumnya dan penelitian pada novel pada khususnya. Disarankan kepada peneliti lain yang berminat mengkaji teks sastra, hendaknya diperhatikan bahwa hasil penelitiannya harus mempunyai relevansi dengan pengajaran bahasa Indonesia keberadaan penelitian yang dilakukan akan lebih bermanfaat.

Dapat dilakukan penelitian lebih lanjut terhadap novel Kutukan Tanah Buton baik dari segi bahasanya maupun yang lainnyakarena penelitian ini masih memiliki banyak kekurangan, masih banyak beberapa jenis gaya bahasa yang belum didenifikasi, dan analisis makna gaya bahasa yang belum tajam.apabila dilakukan penelitian lebih lanjut terhadap novel Kutukan Tanah Buton karya Safarudin, diharapkan hasil penelitian dapat melengkapi kekurangan penelitian ini

\section{DAFTAR PUSTAKA}

Adampe, Regina Yolanda. 2015. Tinjauan Sosiologi Terhadap Novel Detik Terakhir Karya Alberthiene Endah.(Online),

(http:Journal.unnes.ac.Id/sju/index.php/jsi/ article/view/3964/359). Diakses Tanggal 27-10-2018.

Endraswara, Suwardi. 2011. Metodologi Penelitian Sastra. Yogyakarta:CAPS

Endraswara, Suwardi. 2003.Metodologi Penelitian Sastra. Yogyakarta: CAPS

Fajri, Em Zul dan Ratu Aprilia Senja. 2008. Kamus Lengkap Bahasa Indonesia. Tulung Agung: Diva Publisher.

Keraf, Gorys. 2004. Diksi dan Gaya Bahasa. Jakarta: PT Gramedia Pustaka Utama.

Kosasih, Encang. 2003. Kompetensi Ketatabahasaan dan Kesusastraan.Bandung: Yrama Widya.

Laila, Aruna. 2016. Gaya Bahasa Perbandingan Dalam Kumpulan Puisi Melihat Api Bekerja Karya M Aan Mansyur. Jurnal Gramatikka STKIP PGRI SumateraBarat.(Online), (https://www.neliti.com/publicati ons/79994/gaya-bahasaperbandingan-dalam kumpulanpuisi-melihat-api-bekerja-karya$\mathrm{M}$ aan-mansyur). Diakses tanggal 28-10-2018.

Murpratama, Dian Ayu. Aspek Sosial Salam Novel Pusaran Arus Waktu KArya Gola Gong Tinjauan Sosiologi Sastra Dan Implementasinya Dalam 
Pembelajaran SMA. Aspek Sosial

Novel Pusaran Arus Waktu

Sosiologi Sastra. (Online),

(file://C:/Users/Acer/Dowloads/D

ocuments/Jurnal-Penelitian.pdf).

Diakses tanggal 12-11-2018.

Nurgiyantoro, Burhan. 2010. Teori

Pengkajian Fiksi. Yogyakarta:

Gadja Mada University Press.

Nurgiyantoro, Burhan. 2013. Teori

Pengkajian Fiksi. Yogyakarta:

Gadja Mada University Press.

Padi, Editoria. 2013. Kumpulan Super Lengkap Sastra Indonesia.

Jakarta: Padi

Pradopo, Rachmat Djoko. 2013. Beberapa

Teori Sastra Metode Kritik Dan

Penerapannya. Yogyakarta:

Pustaka Pelajar.

Ratna, Nyoman Kutha. 2008. Teori,

Metode, dan Teknik Peneliti

Sastra. Yogyakarta: Pustaka

Pelajar.

Safarudin. 2018. Kutukan Tanah Buton.

Kendari: Oceania Press.

Semi, M Atar. 1990. Metode Penelitian

Sastra. Bandung: Angkasa.

Waridah, Ernawati. 2009. EYD dan

Seputar Kebahasaan Indonesia.

Jakarta: Kawan Pustaka.

Wellek, Rene dan Austin Warren. 2014.

Teori Kesusastraan. Jakarta: PT

Gramedia Pustaka Utama.

Wicaksono, Andri. 2014. Pengkajian

Prosa Fiksi. Yogyakarta:

Garudhawaca. 